\title{
Organic carbon mineralization of the biochar and organic compost of poultry litter in an Argisol
}

\section{Mineralização de carbono orgânico do biocarvão e do composto orgânico de cama de aviário em um Argissolo}

\author{
Gilvanise Alves Tito'; Josely Dantas Fernandes'; Lúcia Helena Garófalo Chaves²*; \\ Hugo Orlando Carvallo Guerra2; Edilma Rodrigues Bento Dantas ${ }^{3}$
}

\section{Highlights}

The organic compost was obtained by incubating poultry litter for 120 days.

The biochar was obtained by pyrolysis for $3 \mathrm{~h}$ in a muffle furnace.

The highest $\mathrm{C}-\mathrm{CO}_{2}$ mineralization was observed in the treatments with organic compost.

Biochar is efficient in reducing the soil carbon and mitigate the "greenhouse" effect.

\section{Abstract}

The dynamics of the organic residues added to the soil are closely related to its mineralization rate. Therefore, the present study aimed to evaluate the organic carbon mineralization in soil samples incubated with different doses of biochar and organic compost from poultry litter. Carbon mineralization was evaluated experimentally by measuring the $\mathrm{C}-\mathrm{CO}_{2}$ liberated by incubating $200 \mathrm{~g}$ of soil mixed with different doses $0,5,10,15$, and $20 \mathrm{t} \mathrm{ha}^{-1}$ of both biochar and organic compost for 61 days. The soil microbial activity, and consequently the carbon mineralization, increased with the application of doses of biochar and organic compost from the poultry litter. The highest $\mathrm{C}-\mathrm{CO}_{2}$ mineralization was observed in the treatments that received organic compost. The carbon mineralization process followed chemical kinetics with two simultaneous reactions. The greatest amount of released and accumulated $\mathrm{C}-\mathrm{CO}_{2}$ was observed in the soil incubated with 15 and $20 \mathrm{t} \mathrm{ha}^{-1}$ of organic compost from the poultry litter. The doses of biochar did not influence the content of mineralized carbon; this behavior was not verified with the use of this compost, whose highest content corresponded to $85.69 \mathrm{mg} \mathrm{kg}^{-1}$, applying $20 \mathrm{t} \mathrm{ha}^{-1}$.

Key words: Organic substrate. Microbial activity. $\mathrm{C}-\mathrm{CO}_{2}$. Chemical kinetics.

1 Postdoctoral Students, Agricultural Engineering Department, Universidade Federal de Campina Grande, UFCG, Campina Grande, PB, Brazil. E-mail: gilvanisetito@yahoo.com.br; joselysolo@yahoo.com.br

2 Full Profs., Agricultural Engineering Department, UFCG, Campina Grande, PB, Brazil. E-mail: Ingarofalo@hotmail. com; hugo_carvallo@hotmail.com

${ }^{3}$ Dra Researcher, Civil Engineering Department, UFCG, Campina Grande, PB, Brazil. E-mail: edilma.dantas@hotmail. com

* Author for correspondence

Received: Mar. 21, 2021 - Approved: May 31, 2021 


\section{Resumo}

A dinâmica dos resíduos orgânicos adicionados ao solo está intimamente relacionada à sua taxa de mineralização. Para isso, o presente estudo teve como objetivo avaliar a mineralização do carbono orgânico em amostras de solo incubadas com diferentes doses de biocarvão e de composto orgânico da cama de aviário. A mineralização de carbono foi avaliada experimentalmente medindo-se o C- $\mathrm{CO}_{2}$ liberado durante uma incubação de $200 \mathrm{~g}$ de solo misturado com doses de 0, 5, 10, 15 e 20 t ha-1 de biocarvão e de composto orgânico, durante 61 dias. A atividade microbiana do solo e consequentemente a mineralização de carbono aumentaram com a aplicação das doses de biocarvão e de composto orgânico da cama de aviário. A maior mineralização de $\mathrm{C}-\mathrm{CO}_{2}$ foi observada nos tratamentos que receberam composto orgânico. A mineralização do carbono foi um processo dividido em duas fases distintas, a primeira com mineralização intensa e meia-vida curta do carbono e a segunda com processo de mineralização lento, com tendência de redução e estabilização do fluxo de $\mathrm{C}-\mathrm{CO}_{2}$. A mineralização de carbono obtida com os substratos avaliados no presente estudo mostrou que os materiais pirolisados (biocarvão) são bastante eficientes para sequestrar o carbono do solo e mitigar o efeito "estufa".

Palavras-chave: Substrato orgânico. Atividade microbiana. $\mathrm{C}-\mathrm{CO}_{2}$. Cinética química.

\section{Introduction}

The poultry industry in Brazil annually generates more than 6.8 million cubic meters of poultry litter (Corrêa \& Miele, 2011), a material containing high contents of organic carbon, nitrogen, phosphorus, potassium, and other plant nutrients, that is commonly applied to agricultural lands as a soil amendment and organic fertilizer (Guo, Tongtavee, \& Labreveux, 2009). According to Santos and Grangeiro (2013), this organic fertilization constitutes a low-cost and economically viable agricultural technique. However, its repeated application results in a severe nutrients accumulation in the soil, with subsequent flow and lixiviation losses to the underwater reserves causing eutrophication and degradation of soil quality (Boesch, Brinsfield, \& Magnien, 2001). To prevent nutrient wastage, poultry litter is occasionally transformed into an organic compost, comprising relatively stable humic substances that are more suitable for soil fertilization. Another efficient strategy to maintain a more constant and long-term nutrient supply to the plants and prevent rapid losses is to transform the poultry litter into biochar via pyrolysis.

Biochar reportedly has a higher carbon stability than organic carbon (Wardle, Nilsson, \& Zackrisson, 2008). Kuzyakov, Bogomolova and Glaser (2014) confirmed that biochar is a carbon-rich, highly recalcitrant organic material with a long-term stability. Since biochar retains organic carbon during pyrolysis, its addition to the soil increases the total soil carbon content. (Woolf, Amonette, Street-Perrott, Lehmann, \& Joseph, 2010). This causes reduction of carbon in the soil (Pokharel, Zilong, \& Chang, 2020), which consequently decreases its emission to the atmosphere and reduces the greenhouse effect (Liu et al., 2016). A comparison between the in vitro carbon mineralization kinetics of several biochars and that of a wheat straw, in three different soils, revealed a higher carbon mineralization and lower half-life of the wheat straw when compared to the biochars 
(Qayyum, Steffens, Reisenauer, \& Schubert, 2012).

The mineralization of organic matter, essential for soil carbon dynamics, depends on the temperature, soil water content, soil characteristics, and microbial activities, such as respiration. Few short-term incubation studies showed that the biochar in soil can be degraded by both photochemical and microbiological processes (Novak et al., 2009; Zhao, Coles, \& Wu, 2015; Shrestha, Traina, \& Swanston, 2010).

The microbial respiration is quantified using the soil organic matter oxidation, and $\mathrm{CO}_{2}$ emission (Silva, Alburquerque, Santos, Oliveira, \& Guedes, 2013). The microbial respiration indicates improvement and better quality of soil nutrient mineralization.

It has been observed that when biochar is applied to the soil, $10-20 \%$ of the material mineralizes to $\mathrm{CO}_{2}$, and aromatic and aliphatic compounds can precipitate, forming more complex molecules, thus, increasing the resistance to microbial decomposition (Jeffery, Coliins, \& Bailey, 2010). Application of poultry litter biochar in two Argisols showed $\mathrm{CO}_{2}$ mineralization of $12.5 \pm 1.3$ and $7.1 \pm 0.7$ mg CO 2 per day (Sigua et al., 2014).

Little is known about the life of biochar in soil, mainly for two reasons: 1) the recalcitrancy of biochar depends on a series of factors, including the type of biomass used in pyrolysis, production conditions, soil properties, and climate; 2) quantifying the stability of biochar requires long-term observations, which is more than the traditional periods normally considered in experiments. Labile carbon has a medium life of 1-5 years while inert organic carbon, such as biochar, may last thousands of years
(Winsley, 2007). Bruun, Jensen and Jensen (2008) reported that $\mathrm{CO}_{2}$ evolution from plants proceeds with a lag phase, followed by a period of higher evolution, and finally, a period of very low evolution. However, $\mathrm{CO}_{2}$ evolution from the biochar had no lag phase, but fast evolution during the first 5-8 days, followed by a period of slow evolution. The average residence time of biochar varies between 4 and 29 years, depending on the soil type and quality of biochar (Steinbeiss, Gleixner, \& Antonietti, 2009). It has been reported that the biochar degradation rate depends more on the combustion temperature and duration than the source materials (Zimmerman, 2010). The particle size of biochars is an important parameter for their ability to react with soil particles (Laird, Brown, Amonette, \& Lehmann, 2009), and is believed to affect their resistance to microbial mineralization (Manyà, 2012).

The objective of the present work was to study and compare the carbon mineralization of different doses of poultry litter organic compost and its biochar in an Argisol.

\section{Materials and Methods}

The study was conducted at the Irrigation and Salinity Laboratory of the Agricultural Engineering Department, Federal University of Campina Grande, Paraiba State, using an Ultisol Ustults, collected from the Paraíba State, Brazil. The Ultisol was collected from 0-20 cm depth, air-dried, and sieved using a $2.0 \mathrm{~mm}$ sieve. The soil, classified as a loamy sand had the following physico-chemical characteristics: $869.6 \mathrm{~g} \mathrm{~kg}^{-1}$ of sand; $90.4 \mathrm{~g}$ $\mathrm{kg}^{-1}$ of silt and $40.0 \mathrm{~g} \mathrm{~kg}^{-1}$ of clay, soil density $=1.46 \mathrm{~g} \mathrm{~cm}^{3}$; particle density $=2.69 \mathrm{~g} \mathrm{~cm}^{3}$; 
total porosity = $45.73 \% ; \mathrm{pH}\left(\mathrm{H}_{2} \mathrm{O}\right)=5.2 ; \mathrm{Ca}=$ $2.20 \mathrm{cmol}_{\mathrm{c}} \mathrm{kg}^{-1} ; \mathrm{Mg}=2.40 \mathrm{cmol}_{\mathrm{c}} \mathrm{kg}^{-1} ; \mathrm{Na}=0.04$ $\mathrm{cmol}_{\mathrm{c}} \mathrm{kg}^{-1} ; \mathrm{K}=0.11 \mathrm{cmol}_{\mathrm{c}} \mathrm{kg}^{-1} ; \mathrm{H}+\mathrm{Al}=2.38$ $\mathrm{cmol}_{\mathrm{c}} \mathrm{kg}^{-1} ; \mathrm{MO}=17.9 \mathrm{~g} \mathrm{~kg}^{-1} ; \mathrm{P}=3.8 \mathrm{mg} \mathrm{kg}^{-1}$ and CTC $=7.13 \mathrm{cmol}_{\mathrm{c}} \mathrm{kg}^{-1}$ (Teixeira, Donagemma, Fontana, \& Teixeira, 2017).

The organic compost was obtained by incubating poultry litter for 120 days, maintaining its humidity close to the field capacity of the soil, and mixing it periodically until a decomposed humic material was formed. The resultant compost was dried, sieved using a $2.0 \mathrm{~mm}$ sieve, and chemically characterized, according to the Manual of Official Analytical Methods for Fertilizers and Correctives (Ministério da Agricultura, Pecuária e Abastecimento [MAPA], 2017). The following characteristics were observed: Total Nitrogen $=24.00 \mathrm{~g} \mathrm{~kg}^{-1} ; \mathrm{P}_{2} \mathrm{O}_{5}=5.71 \%$; $\mathrm{K}_{2} \mathrm{O}=4.19 \% ; \mathrm{Ca}=6.22 \% ; \mathrm{Mg}=1.08 \% ; \mathrm{pH}=$ 9.37; organic carbon $=237.30 \mathrm{~g} \mathrm{~kg}^{-1} ; \mathrm{C} / \mathrm{N}$ ratio = 9.93; and cation exchange capacity $(C E C)=$ $82.47 \mathrm{cmolc} \mathrm{kg}^{-1}$.

The biochar was generated through pyrolysis by putting a mixture of poultry litter bed and poultry wastes in a muffle furnace for $3 \mathrm{~h}$, at a temperature of $350^{\circ} \mathrm{C}$, in the absence of oxygen, to undergo thermal decomposition. After approximately $24 \mathrm{~h}$, the cooled biochar was removed from the muffle furnace. Chemical analysis of the biochar, according to the Manual of Official Analytical Methods for Fertilizers and Correctives (MAPA, 2017) developed for vegetal charcoal, presented the following results: Total Nitrogen $=30.6 \mathrm{~g} \mathrm{~kg}^{-1}$; $\mathrm{P}_{2} \mathrm{O}_{5}=5.76 \% ; \mathrm{K}_{2} \mathrm{O}=6.61(\%) ; \mathrm{Ca}=5.27 \% ; \mathrm{Mg}$ $=1.08 \% ; \mathrm{pH}=8.97 ;$ Organic Carbon $=400.2 \mathrm{~g}$ $\mathrm{kg}^{-1} ; \mathrm{C} / \mathrm{N}$ Ratio $=13.08$ and $\mathrm{CEC}=58.61 \mathrm{cmol}_{\mathrm{c}}$ $\mathrm{kg}^{-1}$.
A randomized experimental design was adopted, using the two substrates, organic compost and biochar, both in the following dosages: 0 (control), 5, 10, 15, and $20 \mathrm{t} \mathrm{ha}^{-1}$, that is, $0.00,0.39,0.77,1.16$, and $1.55 \mathrm{~g}$, respectively, in $200 \mathrm{~g}$ of soil. Additionally, three repeat experiments were also set up, making 30 experimental units. The $200 \mathrm{~g}$ soil mixtures, with the respective doses of the two substrates, were placed in $1.3 \mathrm{~L}$ respirometer pots and dampened with distilled water to increase the water content of the soil by $60 \%$ of the field capacity. A $50 \mathrm{ml}$ beaker, containing $20 \mathrm{ml}$ of $0.5 \mathrm{~mol} \mathrm{~L}^{-1} \mathrm{NaOH}$, was placed in each pot, to adsorb the $\mathrm{C}-\mathrm{CO}_{2}$ released by the treatment. After this, the respirometer pots were hermetically sealed to prevent the entry of atmospheric $\mathrm{CO}_{2}$ and the exit of experimentally produced $\mathrm{CO}_{2}$. The pots were kept in a closed, dark chamber, at a temperature of $27^{\circ} \mathrm{C}$, for 61 days. The evolved $\mathrm{C}-\mathrm{CO}_{2}$ was measured each day, for the first 10 days, followed by measurement on the $14^{\text {th }}$, $19^{\text {th }}, 27^{\text {th }}, 37^{\text {th }}$, and $61^{\text {th }}$ days, since the start of incubation. After each evaluation, the $\mathrm{NaOH}$ solution was replaced.

The liberated $\mathrm{CO}_{2}$ was quantified by titrating the $\mathrm{NaOH}$ with standard $0.4 \mathrm{~mol} \mathrm{~L}^{-1}$ $\mathrm{HCl}$, using 2 drops of $1 \%$ phenolphthalein after the previous precipitation of the carbonate adding $0.5 \mathrm{ml}$ of $1.5 \mathrm{~mol} \mathrm{~L}^{-1} \mathrm{BaCl}_{2}$.

The chemical reactions that occurred in the quantification of $\mathrm{CO}_{2}$ in an alkaline medium are described below by the three equations.

$$
\begin{aligned}
& 2 \mathrm{NaOH}+\mathrm{CO}_{2} \rightarrow \mathrm{Na}_{2} \mathrm{CO}_{3}+\mathrm{H}_{2} \mathrm{O} \\
& \mathrm{Na}_{2} \mathrm{CO}_{3}+\mathrm{BaCl}_{2} \rightarrow \mathrm{BaCO}_{3} \downarrow+2 \mathrm{NaCl} \\
& \mathrm{BaCO}_{3} \downarrow+2 \mathrm{HCl} \rightarrow \mathrm{CO}_{2} \uparrow+\mathrm{BaCl}_{2}+\mathrm{H}_{2} \mathrm{O}
\end{aligned}
$$


The mineralized carbon content was determined following the methodology of Hopkins (2008). The $\mathrm{CO}_{2}$ content that reacted with the $\mathrm{NaOH}$ solution during the incubation was calculated as follows:

$$
\begin{gathered}
\mathrm{CO}_{2 \text { reacted }}=0.5 \times\left(\left(\left(\mathrm{V}_{\mathrm{NaOH}} \times \mathrm{C}_{\mathrm{NaOH}}\right) / 1000\right)-\right. \\
\left.\left(\left(\mathrm{V}_{\mathrm{HCl}} \times \mathrm{C}_{\mathrm{HCl}}\right) / 1000\right)\right)
\end{gathered}
$$

where $\mathrm{V}_{\mathrm{NaOH}}$ and $\mathrm{C}_{\mathrm{NaOH}}$ are the initial volume $(\mathrm{ml})$ and the molar concentration of $\mathrm{NaOH}\left(\mathrm{mol} \mathrm{L}^{-1}\right)$, respectively, and $\mathrm{V}_{\mathrm{HCl}}$ and $\mathrm{C}_{\mathrm{HCl}}$ are the volume (ml) and molar concentration of $\mathrm{HCl}\left(\mathrm{mol} \mathrm{L}^{-1}\right)$ used for titration.

Once the $\mathrm{CO}_{2}$ content was quantified, the mineralized carbon was calculated using the following equation:

$$
\begin{gathered}
\mathrm{C}_{\text {mineralized }}=\mathrm{CO}_{2 \text { reacted }} / \text { (soil mass }(\mathrm{g}) \times \\
\text { incubation time }(\mathrm{h}),
\end{gathered}
$$

The carbon mineralization kinetics can be explained by two models. The first model uses a first-order exponential equation (Murwira, Kirchmann, \& Swift, 1990):

$$
C_{m}=C_{o}\left(1-\mathrm{e}^{-\mathrm{k} \cdot \mathrm{t}}\right)
$$

where $C_{m}$ is the cumulative mineralized organic carbon ( $\mathrm{mg} \mathrm{C}-\mathrm{CO}_{2} \mathrm{~kg}^{-1}$ ) at time $\mathrm{t}$ (days), $\mathrm{C}_{o}$ is the total amount of potentially mineralizable carbon ( $\left.\mathrm{mg} \mathrm{kg}^{-1}\right)$, and $k$ is the constant mineralization rate.

The second model describes carbon mineralization through two simultaneous reactions (Molina, Clap, \& Larson, 1980):

$$
C_{m}=C_{1}\left(1-\mathrm{e}^{-k}{ }_{1} t\right)+C_{2}\left(1-\mathrm{e}_{2}^{-k} \cdot t\right)
$$

where $C_{1}$ and $C_{2}$ are the active and resistant fractions (pools) that are decomposed at mineralization rates $k_{1}$ and $k_{2^{\prime}}$ respectively. The sum of $C_{1}$ and $C_{2}$ has the same physical meaning as $C_{0}$ in the first described model (Foo \& Hameed, 2010).

The parameters of both models were calculated through linear regression, with the Microsoft Office Excel SOLVER tool, using the sum of squared errors (SSE) that represents the difference between the experimental and calculated mineralized carbon (Foo \& Hameed, 2010). The determination coefficients, $R^{2}$ and SSE, were used to compare the model's adjustments.

The carbon mineralization half-life was calculated using the equation of Sposito (2008):

$$
\mathrm{t}_{1 / 2}=\frac{0,693}{k}
$$

The carbon mineralization half-life denotes the time required for the mineralization of half of the potentially mineralizable carbon (Co) during the 61 days of incubation.

The mineralization fraction (MF) was calculated at the end of the incubation period using the following equation:

$$
\mathrm{MF}=100 C_{m} / C_{a}
$$

The mineralization fraction corresponds to the carbon added by the biochar and the organic compost; $C_{m}$ is the difference between the $\mathrm{C}-\mathrm{CO}_{2}$ released and accumulated in the treatment and the control ( $\left.\mathrm{mg} \mathrm{kg}{ }^{-1}\right)$, and $C_{a}$ is the quantity of carbon added by the biochar doses and the organic compost (mg kg-1). 


\section{Results and Discussion}

\section{C- $\mathrm{CO}_{2}$ evolution rate}

The soilmicrobialactivity was evaluated based on the carbon fluxes in the $\mathrm{C}-\mathrm{CO}_{2}$ form. Figures $1 \mathrm{~A}$ and $1 \mathrm{~B}$ show the medium $\mathrm{C}-\mathrm{CO}_{2}$ evolution rates over time during the 61 days incubation period. It was observed that the highest amount of $\mathrm{C}-\mathrm{CO}_{2}$ was liberated on the first day of incubation for both, the highest biochar doses and the organic compost, in almost equal amounts (15.7 $\mathrm{mg} \mathrm{kg}^{-1}$ ), corroborating the results of Shen, Zhu, Cheng, Yue and Li (2017), and Capuani, Rigon, Beltrão and Brito (2012).

In general, the treatments that received different biochar doses exhibited similar behavior after the sixth day where the liberated $\mathrm{C}-\mathrm{CO}_{2}$ decreased with time and stabilized after the 25th day (Figure 1A). This similarity in the $\mathrm{C}-\mathrm{CO}_{2}$ evolution signifies that the biochar doses did not negatively influence the microbial activity.

Till the 19th day, the soils that received the poultry litter organic compost exhibited differences among the $\mathrm{C}-\mathrm{CO}_{2}$ evolution rates for different compost doses, with the lowest gas emission in the control and the highest in the $20 \mathrm{t} \mathrm{ha}^{-1}$ compost dose (Figure 1B).

The $\mathrm{C} / \mathrm{N}$ ratio of the substrate influences their decomposition during carbon mineralization. High $\mathrm{C} / \mathrm{N}$ rates of the compost (9.93) and biochar (13.08), and the temperature and humidity $\left(27{ }^{\circ} \mathrm{C}\right.$ and $60 \%$, respectively), probably promoted favorable conditions for microbial activity and, consequently, for carbon mineralization in the soil (Araújo, Feitosa, Primo, Taniguchi, \& Souza, 2020).

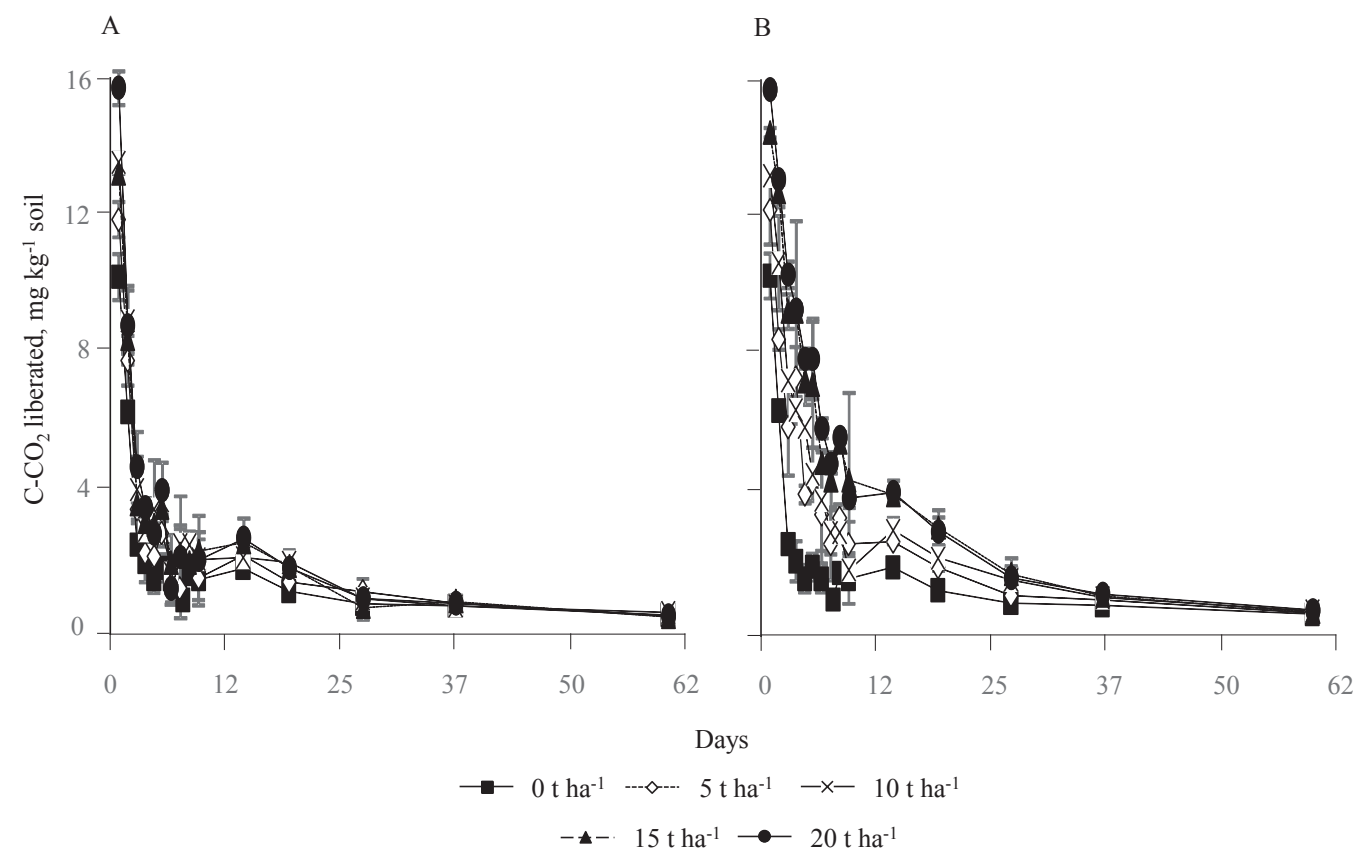

Figure 1. Carbon $\left(\mathrm{C}-\mathrm{CO}_{2}\right)$ evolution rate with time during the 61 days incubation period for the biochar (Fig 1A) and organic compost (Fig IB) treatments. 
During the 61-day period, the daily $\mathrm{C}-\mathrm{CO}_{2}$ evolution, independent of the applied treatments, occurred at a rapid rate in the beginning of the incubation, followed by a lower rate, in the last evaluation period, corroborating the results of Andrade, Bibar, Coscione, Pires and Soares (2015). The rapid decrease in $\mathrm{C}-\mathrm{CO}_{2}$ evolution indicates the presence of organic fractions in the biochar and organic compost.

The biochar has a degradable organic fraction that easily exhausted at the beginning of the incubation process, and a recalcitrant fraction that remained after the degradable sources of carbon were mineralized. These results are corroborated by Cross and Sohi (2011), and Sagrilo, Jeffery, Hoffland and Kuyper (2015). The $\mathrm{C}-\mathrm{CO}_{2}$ evolution decreases in soils incubated with biochar (Shen et al., 2017; Bramble, Gouveia, \& Ramnarine, 2019), suggesting a low amount of degradable substrate, and access of more recalcitrant by the microbes with time, at lower rates (Andrade, Oliveira, \& Cerri, 2006).

The differences in the $\mathrm{C}-\mathrm{CO}_{2}$ evolution during the first 19 days, for different doses of the two substrates, shows that the organic compost has a larger amount of degradable carbon than the biochar.
Capuani et al. (2012) evaluated the microbial activity in different soils when applied with castor bean "pie" and corn textile residues. They verified that more $\mathrm{CO}_{2}$ was produced at the beginning of the decomposition and decreased thereafter.

\section{Accumulated carbon in the $\mathrm{C}-\mathrm{CO}_{2}$ form}

During the 61 days of incubation, a cumulative increase of $\mathrm{C}-\mathrm{CO}_{2}$ was observed due to the application of increasing doses of biochar and organic compost (Figures 2A and 2B). The observation is in agreement with the results of Sistani, Simmons, Jn-Baptiste and Novak (2019), and Bramble et al. (2019).

Comparing the evolution of $\mathrm{C}-\mathrm{CO}_{2}$ production among the doses of $20 \mathrm{t} \mathrm{ha}^{-1}$ for both substrates, it was verified that the soil incubated with the organic compost liberated $158.84 \mathrm{mg} \mathrm{C}-\mathrm{CO}_{2} \mathrm{~kg}^{-1}$ of soil, an increase of $55.84 \%$ when compared with the soil incubated with biochar, which liberated

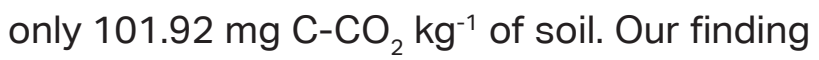
supported the results of Andrade et al. (2015), who studied the carbon mineralization of the poultry litter bed and observed that the $\mathrm{C}-\mathrm{CO}_{2}$ accumulated in the biochar treatment was $30 \%$ lower than that of the organic compost treatment. 


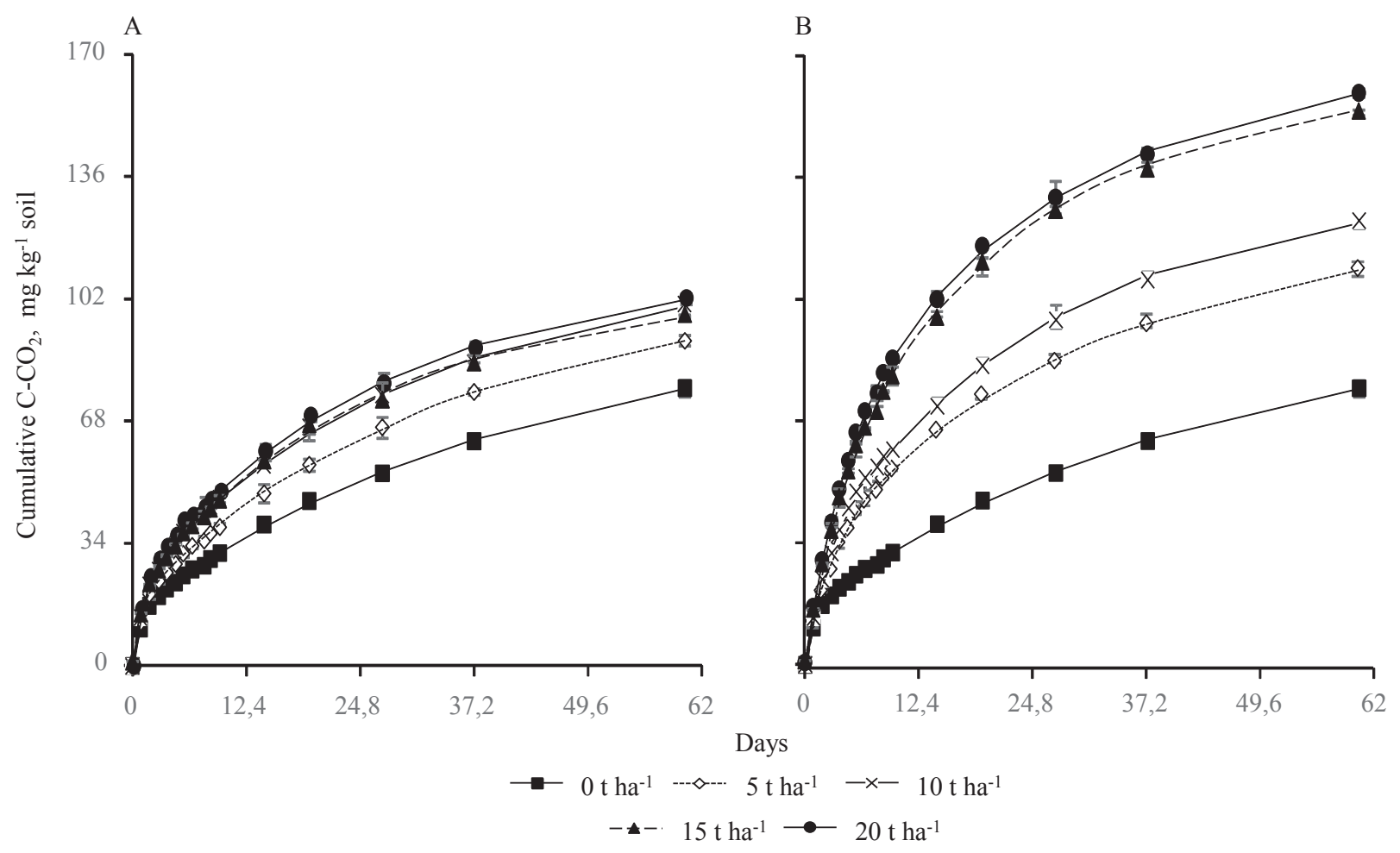

Figure 2. Carbon $\left(\mathrm{C}-\mathrm{CO}_{2}\right)$ liberated and accumulated during the 61 days incubation period for the biochar (Fig 2A) and organic compost (Fig 2B) soil mixed treatments.

As shown in Figure 2A, during the first five days of incubation, the $\mathrm{C}-\mathrm{CO}_{2}$ accumulation was similar (mean of $31.0 \mathrm{mg}$ $\mathrm{kg}^{-1}$ ) for the doses of biochar applied. After this, it was verified that the accumulation of organic carbon increased by $32.2 \%$ with the application of $20 \mathrm{t} \mathrm{ha}^{-1}$ of biochar $(101.9 \mathrm{mg}$ $\mathrm{kg}^{-1}$ ) compared to the control (77.1 $\left.\mathrm{mg} \mathrm{kg}^{-1}\right)$.

When using the organic compost (Figure 2B), the $\mathrm{C}-\mathrm{CO}_{2}$ accumulation was similar for the doses applied only during the first three days of incubation, differing afterward, with an increase of $\mathrm{C}-\mathrm{CO}_{2}$ with the higher compost doses; higher liberation was observed at doses of 15 and $20 \mathrm{t} \mathrm{ha}^{-1}$. An increase of $106.02 \%$ was obtained for the doses of $20 \mathrm{t} \mathrm{ha}^{-1}$ of compost (158.84 $\mathrm{mg} \mathrm{kg}^{-1}$ ) when compared with the control $\left(77.1 \mathrm{mg} \mathrm{kg}^{-1}\right)$. These results indicate a positive contribution of the organic compost to the soil microbial activity, and is consistent with the results found by Steiner, Melear, Harris and Das (2011).

The carbon mineralization results for the doses of biochar and organic compost after 61 days of incubation are presented in Table 1.

The application of $5 \mathrm{t} \mathrm{ha}^{-1}$ of biochar showed the highest mineralization fraction, MF (1.69\%), decreasing with the biochar doses (Table 1). The low MF values obtained with higher doses reinforces the assumption that there are recalcitrant compounds in its structure, that is, of difficult biological degradation in the soil. (Sagrilo et al., 2015; 
Andrade et al., 2006). Sigua et al. (2014) found a higher MF of $4.3 \%$ when poultry litter biochar was mixed with soil (5.110 $\mathrm{mg} \mathrm{kg} 1$ of C) and incubated for 50 days.

The MFs were higher in the organic compost than biochar, for all doses, with an average $7.21 \%$ total added carbon in 5 $\mathrm{t} \mathrm{ha}^{-1}$ of compost. This rate was inferior to the one obtained by Andrade et al. (2015) that had a value of $49.7 \%$. The low carbon mineralization of the organic compost found in the present study may be associated with the utilized biomass, containing chicken excreta, sugarcane residues, and other rations given to the poultry. The poultry ration was formulated using corn, soybean, calcareous, calcic phosphate and a supplement of amino acids, vitamins, minerals, and antibiotics such as salinomycin, a growth promoter (Dalólio, Silva, Baêta, Tinôco, \& Carneiro, 2017). According to Chee-Sanford et al. (2009), salinomycin is not completely absorbed by animals and $~ 75 \%$ is probably released into the environment.

\section{Table 1}

Added, liberated and mineralized carbon $\left(\mathrm{mg} \mathrm{kg}^{-1}\right)$, and Mineralization Fraction (MF, \%) of the biochar and organic compost for the different doses applied, after 61 days of incubation

\begin{tabular}{|c|c|c|c|c|}
\hline Dose & Added C (Ca) & Liberated $\mathrm{C}^{(1)}$ & Mineralized C (Cm) & $\mathrm{MF}^{(2)}$ \\
\hline t ha $^{-1}$ & \multicolumn{4}{|c|}{-----------------------------'mg kg'1------------------------ } \\
\hline & \multicolumn{4}{|c|}{ Biochar } \\
\hline 0 & - & $77.29( \pm 3.06)$ & - & - \\
\hline 5 & 780.39 & $90.50( \pm 5.22)$ & 13.22 & $1.69( \pm 0.1)$ \\
\hline 10 & 1540.77 & $100.77( \pm 1.86)$ & 23.48 & $1.52( \pm 0.15)$ \\
\hline 15 & 2321.16 & $96.54( \pm 1.06)$ & 19.25 & $0.83( \pm 0.17)$ \\
\hline \multirow[t]{2}{*}{20} & 3101.55 & $102.32( \pm 5.77)$ & 25.03 & $0.81( \pm 0.15)$ \\
\hline & \multicolumn{4}{|c|}{ Organic Compost } \\
\hline 0 & - & $77.29( \pm 3.06)$ & - & - \\
\hline 5 & 462.74 & $110.66( \pm 4.13)$ & 33.37 & $7.21( \pm 1.55)$ \\
\hline 10 & 913.61 & $124.00( \pm 6.22)$ & 46.71 & $5.11( \pm 0.89)$ \\
\hline 15 & 1376.34 & $153.35( \pm 5.11)$ & 76.06 & $5.53( \pm 0.44)$ \\
\hline 20 & 1839.08 & $159.12( \pm 0.81)$ & 81.83 & $4.45( \pm 0.21)$ \\
\hline
\end{tabular}

(1) Mean \pm standard error; ${ }^{(2)} \mathrm{MF}(\%)=100 \mathrm{Cm} / \mathrm{Ca} ; \mathrm{Cm}=$ mineralized carbon calculated by the difference among the liberated and accumulated $\mathrm{C}-\mathrm{CO}_{2}$ in the treatment and in the control; $\mathrm{Ca}=$ carbon added to the soil.

Although the amount of accumulated $\mathrm{C}-\mathrm{CO}_{2}$ increased with the substrate doses (Figure 2A and 2B), the MF decreased (Table 1), similar to the results of Andrade etal. 2006). The metabolic needs of the microorganisms were overcome due to the carbon-rich substrate added, thus, incapacitating the degradation of the excess organic carbon. Furthermore, the respiration of microorganisms generate a great demand for oxygen, resulting in low 
aeration in the substrate, prejudicing the remaining carbon consumption (Khalil et al., 2002).

\section{Mineralized Carbon}

The cumulative mineralizable carbon $\left(C_{m}\right)$ of the substrates were evaluated by calculating the difference between the liberated and accumulated $\mathrm{C}-\mathrm{CO}_{2}$ in the treatments (Table 1).
At the lowest dose, the $\mathrm{C}_{\mathrm{m}}$ of the incubated poultry bed was $64.27 \%$ more than that of the biochar, and this difference increased with the substrate dose (Figure 3). Carbon mineralization increased significantly $(p<0.01)$, at a rate of $3.496 \mathrm{mg} \mathrm{kg}^{-1}$ per $\mathrm{t}$ $\mathrm{ha}^{-1}$, reaching maximum $\left(85.70 \mathrm{mg} \mathrm{kg}^{-1}\right)$ in the highest dose $\left(20 \mathrm{t} \mathrm{ha}^{-1}\right)$. However, this value was lower than that of Andrade et al. (2015), that had a mineralizable carbon of 1535.47 and $1529.39 \mathrm{mg} \mathrm{kg}^{-1}$ after incubation of soil and plain sand, respectively, with $3101.55 \mathrm{mg}$ $\mathrm{kg}^{-1}$ of organic compost.

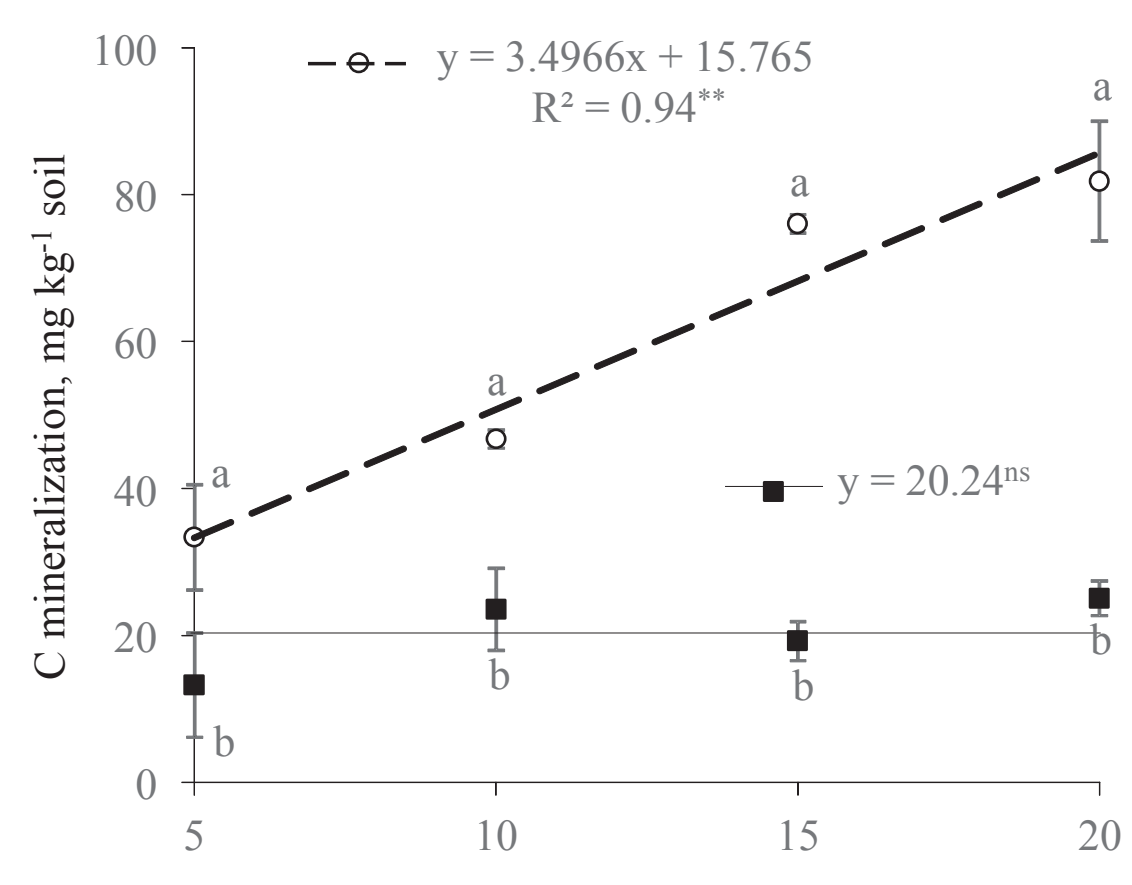

Doses tha ${ }^{-1}$

- Biocarvão - $-\Theta-$ Composto

Figure 3. Mineralized and accumulated Carbon in 61 incubation days for the different added doses of organic compost and biochar.

**, ns significant to the $1 \%$ probability and not significant, respectively, Vertical bars correspond to the standard error intervals. Means followed by the same values are not different among them. 
After incubation of poultry litter with soil and plain sand, Andrade et al. (2015) observed a significant increase in carbon mineralization with the applied doses of poultry litter that corroborates the results obtained in the present study. Similar behavior, independent of the applied dose, was not observed when poultry litter biochar was used. Although the biochar had a carbon (C) content of $400.00 \mathrm{~g}$ $\mathrm{kg}^{-1}$, higher than the organic compost (237.30 $\left.\mathrm{g} \mathrm{kg}^{-1}\right)$, the mineralization rate of biochar was low. This can be explained by the pyrolysis process, where volatile losses (methanol, acetic acid, $\mathrm{CO}, \mathrm{H}_{2}, \mathrm{CO}_{2}$, low mass molecules, fatty acids, oils, and resins) occur, in addition to hemicellulose decomposition and water liberation (Zhao, Cao, Mašek, \& Zimmerman, 2013). Thus, the biochar has a higher stability, due to the variable losses of $\mathrm{H}, \mathrm{O}, \mathrm{C}$, and $\mathrm{N}$, which preserves relatively more carbon, reducing the $\mathrm{H} / \mathrm{C}, \mathrm{O} / \mathrm{C}$, and $(\mathrm{O}+\mathrm{N}) / \mathrm{C}$ ratios (Novak et al., 2009).
The carbon mineralization evaluated in the present study partially corroborates the results of Lehmann, Gaunt and Rondon (2006) that pyrolyzed materials are more efficient in reducing soil carbon and mitigating the greenhouse effect. Bruun and EL-Zehery (2012) evaluating whether the addition of biochar to the soil affects the degradation of litter and of soil organic matter (SOM) found that the biochar mineralization occurred more slowly when compared to litter and soil organic matter, confirming its high stability.

\section{Kinetic study}

The $\mathrm{C}-\mathrm{CO}_{2}$ mineralization obtained in the present study adjusted satisfactorily to the two kinetic models (first-order and two simultaneous reaction) (Table 2). 


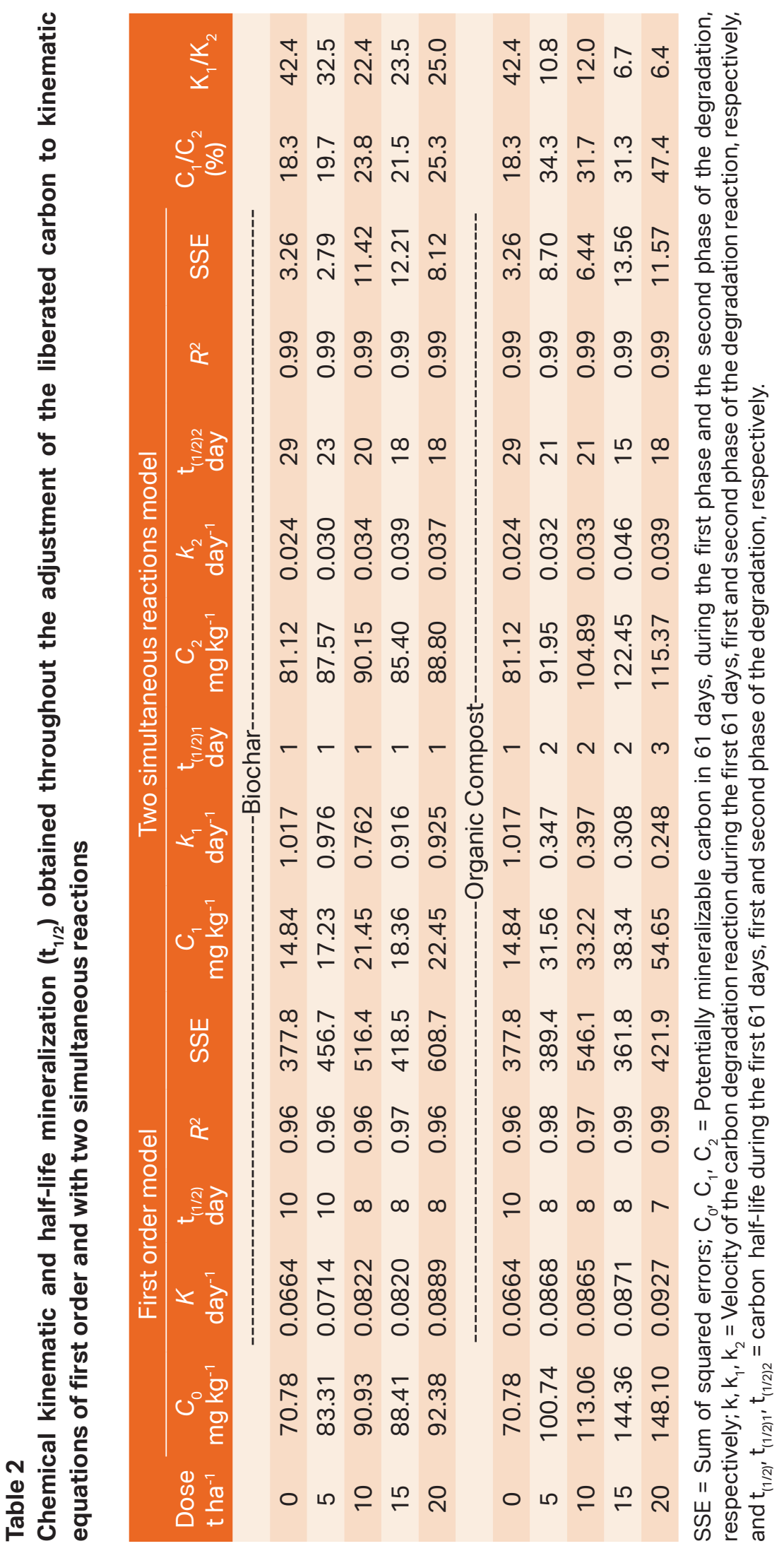


The determination coefficient $\left(\mathrm{R}^{2}\right)$ and the SSE show the efficiency of adjustment between the model estimates and the experimental data. The second model, using two simultaneous reactions, was the most efficient, describing $99 \%$ of the mineralization, carbon variation with time, and incubation conditions. This model also showed lower SSE values, independent of the substrate and doses utilized.

The two simultaneous reactions model suggests that the carbon mineralization is a biphasic process: the first stage $\left(C_{1}\right)$ is characterized by an initial increase of the microbial activity, when the labile organic carbon is easily degraded and exhausted, and the second stage $\left(\mathrm{C}_{2}\right)$, when the microorganisms start to use the most recalcitrant carbon, and the mineralization becomes relatively stabilized (Figure 2). This inference is supported by the studies of Ribeiro et al. (2010) and Rivas, Tabatabai, Olk and Thompson (2014).

According to Dodor, Amanor, AsamoahBediako, Maccarthy and Dovie (2019), the proportion of labile organic and recalcitrant carbon determines its mineralization rate and potential $\mathrm{CO}_{2}$ emission when applied to the soil. The low $C_{1} / C_{2}$ proportion of the biochar suggests that it contains more recalcitrant compost as compared to labile carbon. The low labile carbon, degraded in the first stage $\left(C_{1}\right)$, consisted of small, volatile aliphatic composts, low carbon content in its structure, and the presence of oxygenated groups, which induced a mineralization greater than in the second stage $\left(\mathrm{C}_{2}\right)$. In the second stage, the presence of more stable carbon, nonvolatile aromatic composts, and low concentration of oxygen in its structure caused low carbon mineralization. These data corroborate the findings of Zimmerman, Gao and Ahn (2011).

The soil incubated with biochar presented a lesser amount of potentially mineralizable carbon, in both phases $C_{1}$ and $\mathrm{C}_{2}$, independent of the applied doses, than the one verified for the soil incubated with organic compost. The highest $\mathrm{C}_{1} / \mathrm{C}_{2}$ ratio for biochar was $25.3 \%$ at 20 t ha $^{-1}$. The organic compostincubated soil presented $\mathrm{C}_{1} / \mathrm{C}_{2}$ ratio of $47.4 \%$ at $20 \mathrm{t} \mathrm{ha}^{-1}$ (Table 2). The high $\mathrm{C}_{1} / \mathrm{C}_{2}$ obtained for the organic compost is justified by the high labile carbon content of this substrate. Increase in the carbon mineralization observed with the dose application for the organic compost was due to the increase in the readily mineralizable carbon (Cross \& Sohi, 2011; Fernández et al., 2014).

In general, independent of the substrate used and the applied dose, the first phase of the organic material degradation was characterized by an elevated velocity $\left(\mathrm{K}_{1}\right)$, which was higher to the velocity of the second phase $\left(\mathrm{K}_{2}\right)$ (Table 2). The higher $\mathrm{K}_{1}$ velocities of the biochar-incubated soil were due to the lower concentration of labile carbon in the substrate during the first phase. In the second phase, although the organic compost had a high content of mineralizable carbon, its mineralization velocity $\left(\mathrm{K}_{2}\right)$ was similar to that of the biochar, independent of the applied dose. The difference between the carbon degradation velocity in the first and second phases of the process can be observed from the $\mathrm{K}_{1} / \mathrm{K}_{2}$ ratio (Table 2), which is an indication of how high the degradation velocity of the first phase is when compared with the second phase. As expected, and already discussed, the higher $\mathrm{K}_{1} / \mathrm{K}_{2}$ values observed for the biochar indicate higher organic material 
degradation velocity of the first phase when compared with the second phase (Zhao, et al., 2015; Zimmerman et al., 2011).

The half-life values $\left(t_{1 / 2}\right)$ (time required for half of the carbon be mineralized) of the biochar-incubated treatments (Table 2), independently of the applied dose, indicate that during the first phase of the carbon degradation, half of the carbon degraded on the first day of incubation. For the treatments with organic compost, the half-life increased with the applied dose, obtaining the highest $t_{1 / 2}$ after 3 days, at $20 \mathrm{t} \mathrm{ha}^{-1}$. During the second phase, due to the presence of recalcitrant materials in both substrates, the values of $t_{1 / 2}$ were high, indicating that more time is required for mineralization.

Although the kinetics study confirms that the biochar has a more stable carbon fraction than the organic compost, the amount of carbon materials readily degradable by soil microbes over time is still small.

Due to rapid initial mineralization, the biochar was able to release nutrients for the plants on the first day of incubation, corroborating the results of Fernandes, Chaves, Mendes, Chaves and Tito (2018), who verified significant improvements in soil fertility when it was incubated with poultry litter biochar.

\section{Conclusion}

1. The soil microbial activity and carbon mineralization increased with the application of substrate doses of biochar and organic compost made from poultry litter bed.

2. The highest $\mathrm{C}-\mathrm{CO}_{2}$ mineralization was observed in the treatments that received organic compost.
3. The carbon mineralization process was divided into two different phases, the first with an intense mineralization and a short halflife, and the second with a slow mineralization process, with a tendency to reduce and stabilize the $\mathrm{C}-\mathrm{CO}_{2}$ flux.

4. The carbon mineralization obtained with the substrates evaluated in the present study showed that the pyrolyzed materials (biochar) are efficient in reducing the soil carbon and mitigating the "greenhouse" effect.

\section{Acknowledgements}

The first author would like to thank the National Council for Scientific and Technological Development (CNPq) for granting the scholarships.

\section{References}

Andrade, C. A., Bibar, M. P. S., Coscione, A. R., Pires A. M. M., \& Soares, Á. G. (2015). Mineralização e efeitos de biocarvão de cama de frango sobre a capacidade de troca catiônica do solo. Pesquisa Agropecuária Brasileira, 50(5), 407-416. doi: 10.1590/S0100-20 $4 \times 2015000500008$

Andrade, C. A., Oliveira, C., \& Cerri, C. C. (2006). Cinética de degradação da matéria orgânica de biossólidos após aplicação no solo e relação com a composição química inicial. Bragantia, 65(4), 659668. doi: 10. 1590/S000687052006000400017

Araújo, M. D. M., Feitosa, M. M., Primo, A. A., Taniguchi, C. A. K., \& Souza, H. A. (2020). Mineralization of nitrogen and carbon from organic compost from animal production 
waste. Revista Caatinga, 33(2), 310-320. doi: 10.1590/1983-21252020v33n204rc

Boesch, D. F., Brinsfield, R. B., \& Magnien, R. E. (2001). Chesapeake bay eutrophication: scientific understanding, ecosystem restoration, and challenges for agriculture. Journal Environmental Quality, 30(2), 303320. doi: 10.2134/jeq2001.302303x

Bramble, D. S. E., Gouveia, G. A., \& Ramnarine, R. (2019). Organic Residues and Ammonium Effects on CO2 Emissions and Soil Quality Indicators in Limed Acid Tropical Soils. Soil Systems, 3(16), 1-15. doi: 10.3390/ soilsystems3010016

Bruun, S., \& El-Zehery, T. (2012). Biochar effect on the mineralization of soil organic matter. Pesquisa Agropecuária Brasileira, 47(5), 665-671. doi: 10.1590/S0100-20 $4 \times 2012000500005$

Bruun, S., Jensen, E. S., \& Jensen, L. S. (2008). Microbial mineralization and assimilation of black carbon: dependency on degree of thermal alteration. Organic Geochemistry, 39(7), 839-845. doi: 10. 1016/j.orggeochem.2008.04.020

Capuani, S., Rigon, J. P. G., Beltrão, N. E. M., \& Brito, J. F., Neto. (2012). Atividade microbiana em solos, influenciada por resíduos de algodão e torta de mamona. Revista Brasileira de Engenharia Agricola e Ambiental, 16(12), 1269-1274. doi: 10. 1590/S1415-43662012001200002

Chee-Sanford, J. C., Mackie, R. I., Koike, S., Krapac, I., Maxwell, S., Lin, Y., \& Aminov, R. I. (2009). Fate and transport of antibiotic residues and antibiotic resistance genetic determinants during manure storage, treatment, and land application. Journal of Environmental Quality, 38(3), 10861108. doi: 10.2134/jeq 2008.0128
Corrêa, J. C., \& Miele, M. (2011). A cama de aves e os aspectos agronômicos, ambientais e econômicos. In J. C. P. Palhares, \& A. Kunz (Eds.), Manejo ambiental na avicultura (pp. 125-152). (Documentos, 149). Concórdia: EMBRAPA Suínos e Aves. Recuperado de http://ainfo.cnptia.embrapa.br/digital/ bitstream/item/57059/1/a-cama-deaves-e-os-aspcteos.pdf

Cross, A., \& Sohi, S. P. (2011). The priming potential of biochar products in relation to labile carbon contents and soil organic matter status. Soil Biology and Biochemistry, 43(10), 2127-2134. doi: 10. 1016/ j.soilbio.2011.06.016

Dalólio, F. S., Silva, J. N., Baêta, F. C., Tinôco, I. F. F., \& Carneiro, A. C. O. (2017). Cama de frango e resíduo moveleiro: alternativa energética para a zona da mata mineira. Revista Engenharia na Agricultura, 25(3), 261-271. doi: 10.13083/reveng.v25i3.734

Dodor, D. E., Amanor, Y. J., Asamoah-Bediako, A., Maccarthy, D. S., \& Dovie, D. B. K. (2019). Kinetics of carbon mineralization and sequestration of sole and/or co-amended biochar and cattle manure in a sandy soil. Communications in Soil Science and Plant Analysis, 50(20), 2593-2609. doi: 10. 1080/00103624.2019.1671443

Fernandes, J. D., Chaves, L. H. G., Mendes, J. S., Chaves, I. B., \& Tito, G. A. (2018). Soil chemical amendments and the macronutrients mobility evaluation in oxisol treated with biochar. Journal of Agricultural Science, 10(10), 238-247. doi: 10.5539/jas.v10n10p238

Fernández, J. M., Nieto, M. A., López-De-Sá, E. G., Gascó, G., Méndez, A., \& Plaza, C. (2014). Carbon dioxide emissions from semi-arid soils amended with biochar 
alone or combined with mineral and organic fertilizers. Science of the Total Environment, 482-483(1), 1-7. doi: 10.10 16/j.scitotenv.2014.02.103

Foo, K. Y., \& Hameed, B. H. (2010). Insights into the modeling of adsorption isotherm systems. Chemical Engineering Journal, 156(1), 2-10. doi: 10.1016/j.cej. 2009.09.013

Guo, M., Tongtavee, N., \& Labreveux, M. (2009). Nutrient dynamics of field-weathered Delmarva poultry litter: implications for land application. Biology and Fertility of Soils, 45(8), 829-838. doi: 10.1007/s00 374-009-0397-4

Hopkins, D. W. (2008). Carbon mineralization. In M. R. Carter, \& E. G. Gregorich (Eds.), Soil sampling and methods of analysis (2a ed., pp. 621-626). Boca Raton: CRC Press.

Jeffery, L. S., Coliins, H. P., \& Bailey, V. L. (2010). The effect of young biochar on soil respiration. Soil Biology \& Biochemistry, 42(12), 2345-2347. doi: 10.1016/j.soilbio. 2010.09.013

Khalil, M. I., Rosenani, A. B., Van Cleemput, O., Boeckx, P., Shamahuddin, J., \& Fauziah, C. I. (2002). Nitrous oxide production from an Ultisol of the humid tropics treated with different nitrogen sources and moisture regimes. Biology and Fertility of Soils, 36(1), 59-65. doi: 10.1007/s00374-0020505-1

Kuzyakov, Y., Bogomolova, I., \& Glaser, B. (2014). Biochar stability in soil: decomposition during eight years and transformation as assessed by compound-specific 14C analysis. Soil Biology and Biochemistry, 70(3), 229-236. doi: 10.1016/j.soilbio. 2013.12.021
Laird, D. A., Brown, R. C., Amonette, J. E., \& Lehmann, J. (2009). Review of the pyrolysis platform for coproducing bio-oil and bio-char. Bioproducts and Biorefining, 3(5), 547-562. doi: 10.1002/bbb.169

Lehmann, J., Gaunt, J., \& Rondon, M. (2006). Biochar sequestration in terrestrial ecosystems a review. Mitigation and Adaptation Strategies for Global Change, 11(2), 403-427. doi: 10.1007/s11027-005 $-9006-5$

Liu, S., Zhang, Y., Zong, Y., Hu, Z., Wu, S., Zhou, J.,... Zou, J. (2016). Response of soil carbon dioxide fuxes, soil organic carbon and microbial biomass carbon to biochar amendment: a meta-analysis. GCB Bioenergy, 8(2), 392-406. doi: 10.1111/ gcbb. 12265

Manyà, J. J. (2012). Pyrolysis for biochar purposes: a review to establish current knowledge gaps and research needs. Environmental Science \& Technology, 46(15), 7939-7954. doi: 10.1021/es3010 $29 \mathrm{~g}$

Ministério da Agricultura, Pecuária e Abastecimento(2017). Manualdemétodos analíticos oficiais para fertilizantes e corretivos. Brasília, Secretaria de Defesa Agropecuária: MAPA.

Molina, J. A. E., Clap, C. E., \& Larson, W. E. (1980). Potentially mineralizable nitrogen in soil: the simple exponential model does not apply to the first 12 weeks of incubation. Soil Science Society America Journal, 44(2), 442-443. doi: 10.2136/ sssaj1980.03615995004400020054x

Murwira, H. K., Kirchmann, H., \& Swift, M. J. (1990). The effect of moisture on the decomposition rate of cattle manure. 
Plant and Soil, 122(2), 197-199. doi: 10.1007/BF02851975

Novak, J. M., Lima, I., Xing, B., Gaskin, J. W., Steiner, C., Das, K. C.,... Schomberg, H. (2009). Characterization of designer biochar produced at different temperatures and their effects on a loamy sand. Annals of Environmental Science, 3(1), 195-206. Retrieved from http://hdl. handle.net/2047/d10019637

Pokharel, P., Zilong, M., \& Chang, S. X. (2020). Biochar increases soil microbial biomass with changes in extra and intracellular enzyme activities: a global meta analysis. Shenyang Agricultural University, 2(1), 6579. doi: 10.1007/s42773-020.00039-1

Qayyum, M. F., Steffens, D., Reisenauer, H. P., \& Schubert, S. (2012). Kinetics of carbon mineralization of biochars compared with wheat straw in three soils. Journal of Environmental Quality, 41(4), 1210-1220. doi: $10.2134 /$ jeq2011.0058

Ribeiro, H. M., Fangueiro, D., Alves, F., Vasconcelos, E., Coutinho, J., Bol, R., \& Cabral, F. (2010). Carbon-mineralization kinetics in an organically managed cambic arenosol amended with organic fertilizers. Journal of Plant Nutrition and Soil Science, 173(1), 39-45. doi: 10.1002/ jpln.v173:1

Rivas, F. A., Tabatabai, M. A., Olk, D. C., \& Thompson, M. L. (2014). Kinetics of shortterm carbon mineralization in roots of biofuel crops in soils. Biology and Fertility of Soils, 50(3), 527-535. doi: 10.1007/ s00374-013-0870-y

Sagrilo, E., Jeffery, S., Hoffland, E., \& Kuyper, T. W. (2015). Emission of $\mathrm{CO}_{2}$ from biocharamended soils and implications for soil organic carbon. Global Change Biology Bioenergy, 7(6), 1294-1304. doi: 10.1111/ gcbb.12234

Santos, J. F., \& Granjeiro, J. I. T. (2013). Doses de cama de galinha em relação aos componentes de produção de girassol. Tecnologia \& Ciência Agropecuária, 7(2), 15-20.

Shen, Y., Zhu, L., Cheng, H., Yue, S., \& Li, S. (2017). Effects of biochar application on $\mathrm{CO}_{2}$ emissions from a cultivated soil under semiarid climate conditions in northwest China. Sustainability, 9(8), 1-13. doi: 10.3390/su9081482

Shrestha, G., Traina, S. J., \& Swanston, C. W. (2010). Black carbon's properties and role in the environment: a comprehensive review. Sustainability, 2(1), 294-320. doi: 10.3390/su2010294

Sigua, G. C., Novak, J. M., Watts, D. W., Cantrell, K. B., Shumaker, P. D., Szögi, A. A., \& Johnson, M. G. (2014). Carbon mineralization in two Ultisols amended with different sources and particle sizes of pyrolyzed biochar. Chemosphere, 103(5), 313-321. doi: 10. 1016/j.chemosphere.2013.12.024

Silva, J. M., Alburquerque, L. S. D., Santos, T. M. C. D., Oliveira, J. U. L. D., \& Guedes, E. L. F. (2013). Mineralização de vermicompostos estimada pela respiração microbiana. Revista Verde de Agroecologia e Desenvolvimento Sustentável, 8(4), 132135.

Sistani, K. R., Simmons, J. R., Jn-Baptiste, M., \& Novak, J. M. (2019). Poultry litter, biochar, and fertilizer effect on corn yield, nutrient uptake, $\mathrm{N}_{2} \mathrm{O}$ and $\mathrm{CO}_{2}$ emissions. Environments, 6(55), 1-14. doi: 10.3390/ environments6050055 
Sposito, G. (2008). The chemistry of soils (2nd ed.). New York: Oxford University Press.

Steinbeiss, S., Gleixner, G., \& Antonietti, M. (2009). Effect of biochar amendment on soil carbono balance and soil microbial activity. Soil Biology and Biochemistry, 41(6), 1301-1310. doi: 10.1016/j.soilbio. 2009.03.016

Steiner, C., Melear, N., Harris, K., \& Das, K. C. (2011). Biochar as bulking agent for poultry litter composting. Carbon Management, 2(3), 227-230. doi: 10.4155/cmt.11.15

Teixeira, P. C., Donagemma, G. K., Fontana, A., \& Teixeira, W. G. (2017). Manual de métodos de análise de solo (3a ed. rev. e ampl.). Brasília, DF: EMBRAPA.

Wardle, D. A., Nilsson, M.-C., \& Zackrisson, O. (2008). Fire-derived charcoal causes loss of forest humus. Science, 320(5876), 629. doi: $10.1126 /$ science. 1154960

Winsley, P. (2007). Biochar and bioenergy production for climate change mitigation. New Zealand Science Review, 64(1), 5-10.

Woolf, D., Amonette, J. E., Street-Perrott, F. A., Lehmann, J., \& Joseph, S. (2010). Sustainable biochar to mitigate global climate change. Nature Communications, 1(56), 1-9. doi: 10.1038/ncomms1053
Zhao, L., Cao, X., Mašek, O., \& Zimmerman, A. (2013). Heterogeneity of biochar properties as a function of feedstock sources and production temperatures. Journal of Hazardous Materials, 256/257(7), 1-9. doi: 10.1016/j.jhazmat. 2013.04.015

Zhao, R., Coles, N., \& Wu, J. (2015). Carbon mineralization following additions of fresh and aged biochar to an infertile soil. Catena, 125(2), 183-189. doi: 10.1016/j. catena.2014.10.026

Zimmerman, A. R. (2010). Abiotic and microbial oxidation of Laboratory-Produced Black Carbon (Biochar). Environmental Science \& Technology, 44(4), 1295-1301. doi: 10. 1021/es903140c

Zimmerman, A. R., Gao, B., \& Ahn, M. Y. (2011). Positive and negative carbon mineralization priming effects among a variety of biochar-amended soils. Soil Biology and Biochemistry, 43(6), 11691179. doi: 10.1016/j.soilbio.2011.02.005 